\title{
Corporate Governance: A scientometric analysis
}

\author{
Maliheh Alsadat Kermanian ${ }^{a}$, Soltanali Rafiei ${ }^{a}, H_{\text {Hamed Keyvanfar }}{ }^{a}$ and Soheil Sadi-Nezhad ${ }^{\text {* }}$
}

${ }^{a}$ Department of Statistics and Actuarial Science, University of Waterloo, Waterloo, Canada

\begin{tabular}{l}
\hline C H R O N I C L E \\
\hline Article history: \\
Received January 4, 2019 \\
Received in revised format \\
January 122019 \\
Accepted February 92019 \\
Available online \\
February 62019 \\
\hline Keywords: \\
Corporate Governance \\
Corporate Social Responsibility \\
Board of directors
\end{tabular}

\section{Introduction}

Corporate governance is associated with the collection of processes, mechanisms, and relationships by which most corporations are controlled and managed (Arora \& Dharwadkar, 2011). Governance structures and principles normally determine the distribution of rights and responsibilities among the board of directors, managers, shareholders, creditors, auditors, regulators, and other stakeholders and include the rules and procedures for making decisions in corporate affairs (Ben-Amar et al., 2017). Corporate governance plays essential role for the success of any organizations to prevent any conflicts of interests among stakeholders (Barnea \& Rubin, 2010). Corporate governance aims to develop the company's strategic targets, leadership skills, monitoring the management of the business and reporting to shareholders about dividend policy. Corporate governance incorporates various processes where corporations' goals are adjusted and followed through the context of the social, regulatory and market environment (Yermack, 1996). These include continuous supervision of the decisions of firms, their subsidiaries, and influenced stakeholders. Corporate governance practices are observed as efforts to align the stakeholders' interests. The necessity for corporate governance has come to resolve possible conflicts of interests among stakeholders in firms (Wade et al., 2006). The conflicts of interests happen as a results of diversify wishes between both shareholders and upper management and among shareholders, although other stakeholder relationships are influenced and coordinated through such policy making (Mahoney et al., 1993; Gibbs, 1993; Yermack, 1996; Shleifer et al., 2000).

* Corresponding author.

E-mail address: ssadinej@uwaterloo.ca (S. Sadi-Nezhad)

2019 Growing Science Ltd. doi: 10.5267/j.ac.2019.2.001 
This research includes an extensive review of the studies associated with Corporate Governance. The study uses Scopus database as a primary search engine to collect the necessary data and collects 333 records over the period 2010-2018. The purpose of this research is to investigate the structured study of research activities carried out around the subject of corporate governance which have been published in international, well-known and credible magazines, books and sites. For this purpose, the study searches the phrase corporate governance on Scopus site and detects around 7200 documents and 2000 of highly cited documents are selected for the purpose of the investigation accomplished by a bibliometrics tool. The study limits the survey on published articles over the period 1993-2009 and detects 806 documents among 2000 documents from Scopus

\section{Literature review}

During the past few years, there have been tremendous efforts on evaluation of the effects of corporate governance on firm performance. Wintoki et al. (2012) implemented a well-developed dynamic panel generalized method of moments (GMM) estimator to reduce endogeneity concerns in two perspectives of corporate governance research; namely the impact of board structure on corporate performance and the component of board structure. The estimator includes the dynamic nature of internal governance applications to give valid and powerful features which describe unobserved heterogeneity and simultaneity. They investigated the relationship between board structure and performance based on the GMM estimator in a panel of 6,000 companies using the historical data from 1991 to 2003, and detected no causal relationship between the two components. They described why other estimators ignoring the dynamic relationship between the current governance and the past firm performance yield bias results.

Barnea and Rubin (2010) studied the relationship between firms' corporate social responsibility (CSR) ratings and their ownership and capital structures. They reported that on average, insiders' ownership and leverage were negatively associated with the firm's social rating, while institutional ownership was uncorrelated with it. Assuming that higher CSR ratings was related to higher CSR cost level, the results indicated that insiders induce firms to over-invest in CSR when they spend some cost for doing so. Carter et al. (2010) investigated "the relationship between the number of women directors and the number of ethnic minority directors on the board and important board committees and financial performance measured as return on assets and Tobin's Q". They did not detect a substantial association between the gender or ethnic diversity of the board and financial performance in some US firms. Aggarwal et al. (2011) investigated whether institutional investors could possibly influence on corporate governance by studying portfolio holdings of institutions from 23 different countries over the period 2003-2008 and discovered that firm-level governance was positively related to international institutional investment. They also found that changes in institutional ownership could positively influence on the changes in firm-level governance, but the opposite did not necessarily hold. Firms with higher institutional ownership were more likely to end poorly performing managers and demonstrated some improvements in valuation. The results recommended that international portfolio investment by institutional investors could suggest good corporate governance practices around the world.

Erkens et al. (2012) studied the effect of corporate governance on financial firms' performance from 2007 to 2008 where the financial crisis occurred. They determined that companies with more independent boards and higher institutional ownership faced with more challenges during the crisis period. The reasons were because (1) companies with higher institutional ownership stepped for more risk prior to the crisis, which resulted in larger shareholder losses during the crisis period, and (2) corporations with more independent boards were able to have more equity capital during the crisis, which led to a wealth transfer from existing shareholders to debtholders. Armstrong et al. (2010) reviewed some literature on the role of financial reporting transparency in reducing governance-related agency conflicts among managers and reported on the importance of the role of a commitment to financial reporting transparency in facilitating informal multi-period contracts among managers, directors, etc. 


\section{The most common Keywords}

Table 1 demonstrates some of the most popular keywords associated with corporate governance. As we can observe from the results of Table 1, "Corporate Governance", "Corporate social responsibility", and "Board of directors "are three well recognized keywords used in the literature.

\section{Table 1}

The most popular keywords used in studies associated with Corporate Governance.

\begin{tabular}{|c|c|c|c|}
\hline Words & Occurrences & Words & Occurrences \\
\hline Corporate & 834 & Firm Performance & 20 \\
\hline Governance & 764 & Reporting & 18 \\
\hline Firms & 530 & Boards & 17 \\
\hline Board & 400 & Agency Theory & 16 \\
\hline Performance & 396 & Ownership Structure & 14 \\
\hline Corporate Governance & 327 & Industrial Management & 14 \\
\hline Firm & 311 & Boards Of Directors & 12 \\
\hline CSR & 291 & Agency Costs & 11 \\
\hline Find & 238 & Executive Compensation & 10 \\
\hline Directors & 222 & Governance Approach & 10 \\
\hline Ownership & 219 & Firm Value & 10 \\
\hline Financial & 212 & Industry & 10 \\
\hline Social & 195 & Corporate Strategy & 9 \\
\hline Study & 189 & Institutions & 9 \\
\hline Paper & 177 & Board Composition & 8 \\
\hline Companies & 175 & Shareholder Activism & 8 \\
\hline Disclosure & 160 & Regulation & 8 \\
\hline Institutional & 149 & Institutional Theory & 8 \\
\hline CEO & 149 & Family Firms & 7 \\
\hline Implications & 129 & Earnings Management & 7 \\
\hline Findings & 126 & Investments & 6 \\
\hline Evidence & 62 & Shareholders & 5 \\
\hline Corporate Social Responsibility & 46 & Institutional Framework & 5 \\
\hline Board Of Directors & 39 & Research & 4 \\
\hline Responsibility & 35 & Financial System & 4 \\
\hline China & 34 & Data Envelopment Analysis & 4 \\
\hline Management & 23 & Industrial Performance & 3 \\
\hline
\end{tabular}

As shown in Fig. 1. "governance approach", "industry", "corporate strategy", "board of directors", "investments", "institutional framework", "data envelopment analyses", "firm performance", "shareholders" and "financial system" are the research hotspots with a high frequency of the keywords used in different research studies. The board and audit committee activity and their members' financial sophistication may be some important factors in constraining the propensity of managers to engage in earnings management (Xie et al., 2003).

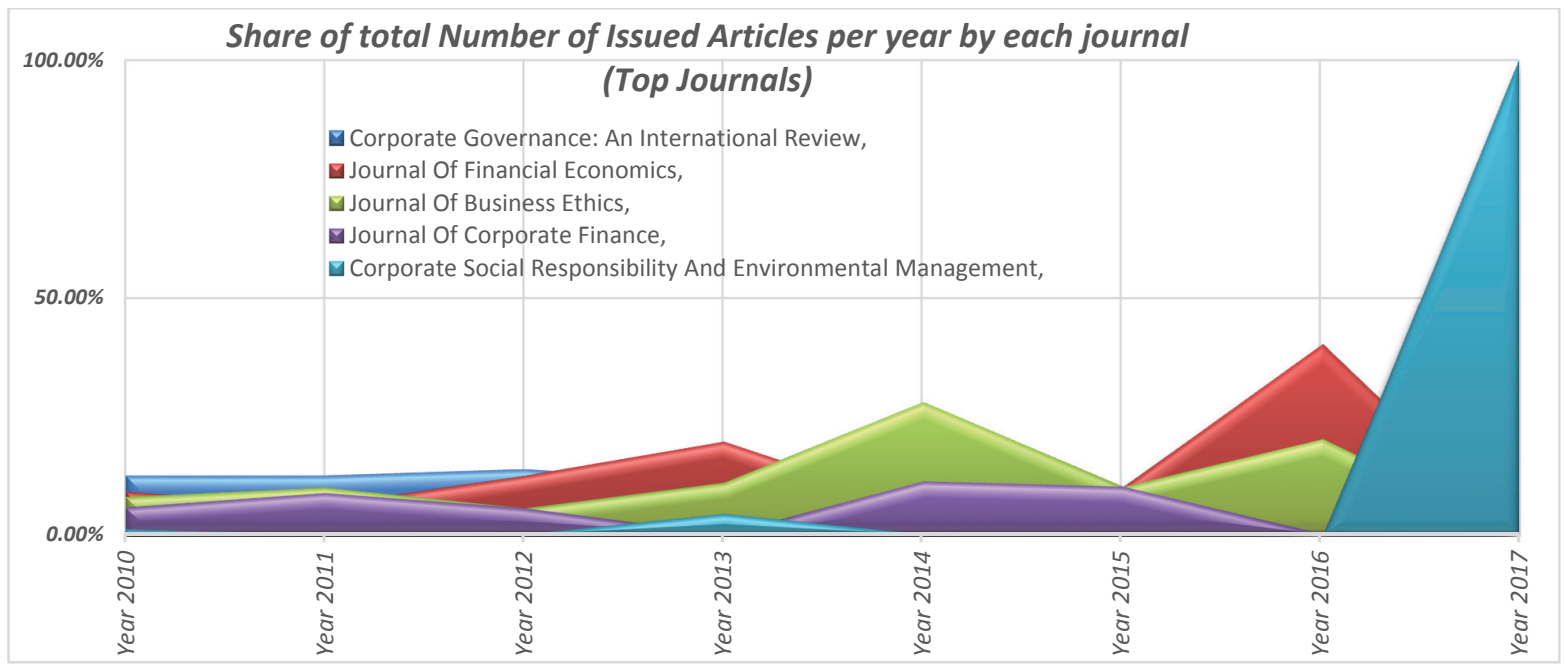

Fig. 3. Share of total Number of Issued Articles per year by each journal 


\section{Contributions of countries}

Our survey demonstrates that United States, United Kingdom, Australia and Canada have maintained the most contribution in the field of corporate governance. From 2000 to 2017, in terms of Average Article Citations; which indicate the number of reference to the articles, the following countries are ranked as the highest Average Article Citations, respectively: Denmark (211), ranked first, Bangladesh (120) and Germany (108.8) are ranked the second and third. With this classification, the United States will be ranked as tenth despite having the highest number of citations. Table 3 shows details of our survey.

\section{Table 3}

The summary of the contributions of different countries

\begin{tabular}{lcclcc}
\hline \multicolumn{1}{c}{ Country } & $\begin{array}{c}\text { Total } \\
\text { Citations }\end{array}$ & $\begin{array}{c}\text { Average } \\
\text { Article Citations }\end{array}$ & Country & $\begin{array}{c}\text { Total } \\
\text { Citations }\end{array}$ & $\begin{array}{c}\text { Average } \\
\text { Article Citations }\end{array}$ \\
\hline USA & 8669 & 78.1 & Greece & 118 & 59 \\
United kingdom & 2094 & 67.5 & Switzerland & 115 & 57.5 \\
Australia & 1557 & 64.9 & Finland & 87 & 43.5 \\
Canada & 1418 & 101.3 & New Zealand & 87 & 43.5 \\
Spain & 897 & 59.8 & Mauritius & 83 & 83 \\
Italy & 708 & 78.7 & Israel & 79 & 79 \\
Germany & 653 & 108.8 & Mexico & 78 & 39 \\
Netherlands & 530 & 48.2 & Poland & 70 & 70 \\
France & 525 & 75 & Costa Rica & 60 & 60 \\
China & 490 & 70 & Iran & 52 & 52 \\
Hong Kong & 402 & 67 & Ireland & 51 & 51 \\
Taiwan & 296 & 42.3 & Nigeria & 40 & 40 \\
Singapore & 282 & 94 & Sweden & 40 & 40 \\
Belgium & 281 & 56.2 & Pakistan & 39 & 39 \\
Korea & 214 & 107 & Ghana & 36 & 37 \\
Denmark & 211 & 211 & Egypt & 36 & 36 \\
Norway & 146 & 48.7 & Portugal & 36 \\
Malaysia & 140 & 46.7 & Colombia & 35 & 35 \\
Bangladesh & 120 & 120 & & & \\
\hline
\end{tabular}

According to Table 3, researchers from United States have published 8669 papers followed by United Kingdom with 2094 papers and Australia with 1557 and Canada with 1418 papers. In terms of the average citation, papers published by researchers in Germany and Canada have maintained the highest citations. Fig. 4 shows the results of the collaborations among various countries.

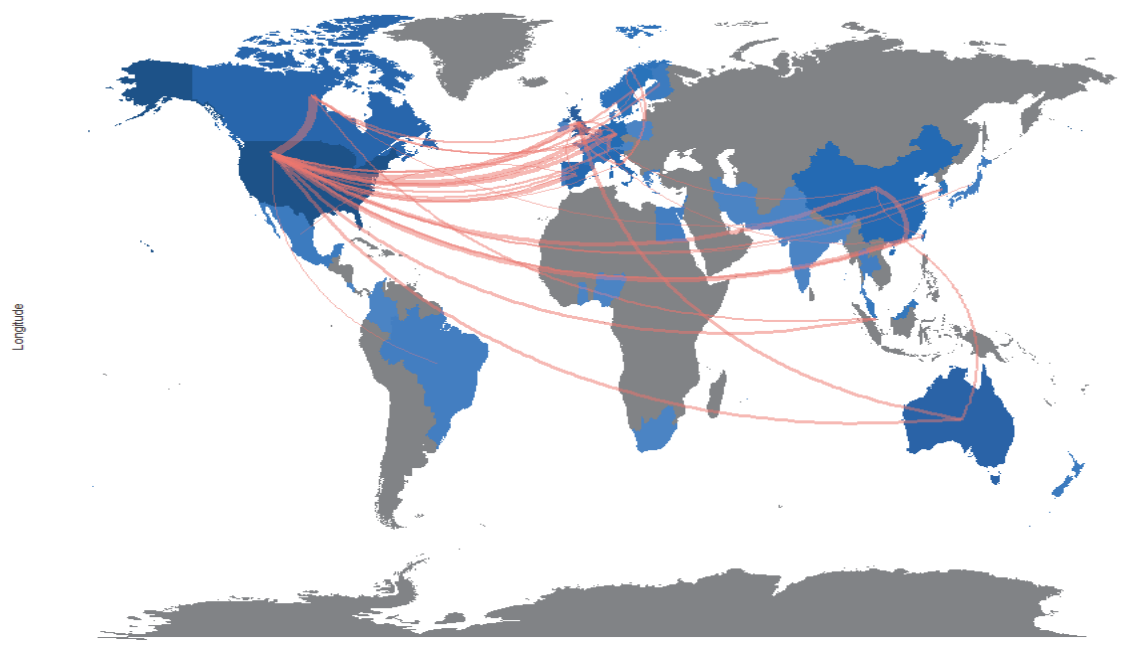

Fig. 4. Country collaboration map

As we can observe from the results of Fig. 4, there were strong collaboration among the researchers in United States from one side and other countries. 


\section{Highly cited papers}

Table 4 shows the summary of the most cited articles. As we can observe from the results of Table 4, the study by Wintoki et al. (2012) has received the highest citations.

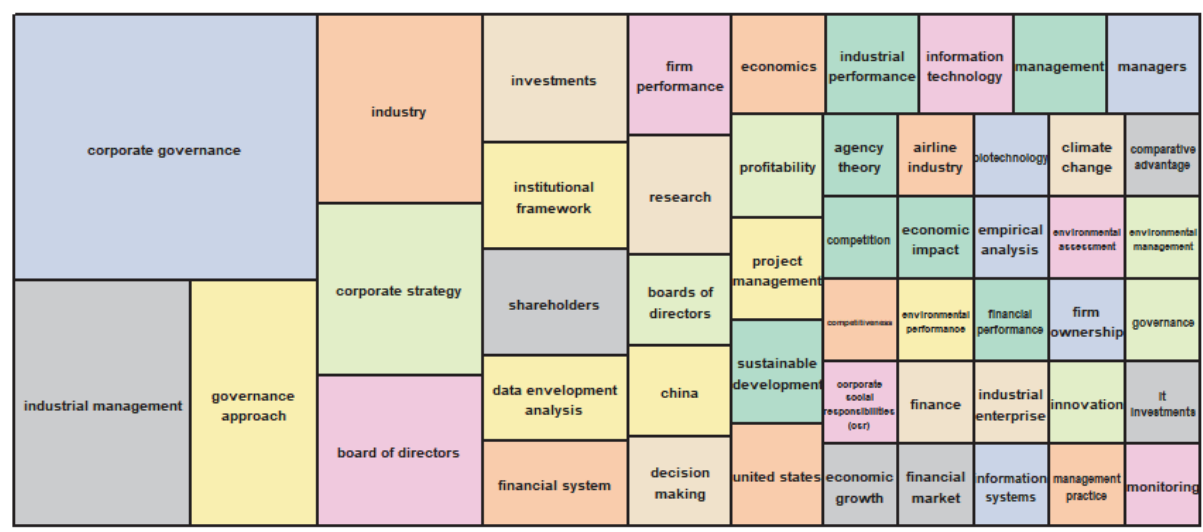

Fig. 5. The word Tree map

Corporate Governance (CG) is one of today's controversial discussions, as it was mentioned earlier. Table 4 presents the order of articles that have received the highest citation in this area.

According to key words used in articles presented in Fig. 5 and what is mentioned above with the most cited articles, we analyze all of the pointed items. The focus of these papers is on the discussion of the impact of CG on firm performance, especially their financial performance. This research suggests that endogeneity concerns of $\mathrm{CG}$ are affecting the performance of the company directly or indirectly (Wintoki et al., 2012; Barnea et al., 2010; Carter et al., 2010; Erkens et al., 2012; Armstrong et al., 2010).

This result supports the hypothesis that there is a dynamic link between CG and firm performance, but this matter is overlooked in many cases. In this regard, we need to consider inner involvements in CG and it has to be dealt with. The effect of CG on CSR is one of the most important issues today. Changes in institutional makeup of the circumstance that companies act in it, lead to changes in CSR. Another set of internal factors that can be pointed out are higher institutional ownership and more independent boards, which affect the performance of firms. In explaining this, we can add that firms with higher institutional ownership take more risks under crisis conditions. The role of independent directors and influential stakeholders were specifically analyzed b Erkens et al. (2012). Transparency of the financial information as one of the CG elements satisfies the interests of both shareholders and other stakeholders in having access to information.

\section{Table 4}

The summary of the most cited articles (Top 60 Articles in total citation)

\begin{tabular}{lcc}
\hline \multicolumn{1}{c}{ Paper } & Total Citations & TC per Year \\
\hline Wintoki Mb, 2012, J Finance Econ (Wintoki et al., 2012) & 420 & 60.00 \\
\hline Barnea A, 2010, J Bus Ethics (Barnea et al., 2010) & 316 & 35.11 \\
Carter DA, 2010, Corp Governance (Carter et al., 2010) & 302 & 33.56 \\
\hline AGGARWAL R, 2011, J Finance Econ (Aggarwal et al., 2011) & 270 & 33.75 \\
Erkens DH, 2012, J Corp Finance (Erkens et al., 2012) & 269 & 38.43 \\
Armstrong CS, 2010, J account Econ (Armstrong et al., 2010) & 266 & 29.56 \\
Brammer S, 2012, Socio-Econ Rev (Brammeret al., 2012) & 262 & 37.43 \\
Jackson G, 2010, J Bus Ethics (Jackson et al., 2010) & 235 & 26.11 \\
Duchin R, 2010, J Finance Econ (Duchin et al., 2010) & 230 & 25.56 \\
Jo H, 2011, J Bus Ethics (Jo et al., 2011) & 219 & 27.38 \\
Torchia M, 2011, J Bus Ethics (Torchia et al., 2011) & 218 & 27.25 \\
\hline
\end{tabular}


Jian M, 2010, Rev Account Stud (Jian et al., 2010)

Roe Mj, 2011, Polit Determ Of Corp Governance : Polit Context, Corp Impact

Claessens S, 2013, Emerge Mark Rev (Claessens et al., 2013)

Aebi V, 2012, J Bank Finance (Aebi et al., 2012)

Brown P, 2011, Account Finance (Brown et al., 2011)

Walls JL, 2012, Strategic Manage J (Walls et al., 2012)

Bebchuk La, 2011, J Finance Econ (Bebchuk et al., 2011)

Khan A, 2013, J Bus Ethics (Khan et al., 2013)

Harjoto Ma, 2011, J Bus Ethics (Harjoto et al., 2011)

Gedajlovic E, 2012, J Manage (Gedajlovic et al., 2012)

Jo H, 2012, J Bus Ethics (Jo et al., 2012)

Song Cj, 2010, Account Rev (Song et al., 2010)

Le Breton-Miller I, 2011, Organ Science (Le Breton-Miller et al., 2011)

Schrand Cm, 2012, J Account Econ (Schrand et al., 2012)

Li W, 2010, J Bus Ethics (Li et al., 2010)

Cohen J, 2010, Contempt Account Res (Cohen et al., 2010)

Masulis Rw, 2012, J Account Econ (Masulis et al., 2012)

Frydman C, 2010, Annul Rev Finance Econ (Frydman et al., 2010)

Kim JB, 2011, J Finance Econ (J.-B. Kim et al., 2011)

Tuggle Cs, 2010, Strategic Manage J (Tuggle et al., 2010)

Frias-Aceituno JV, 2013, Corp Social Responsibly Environ Manage (Frias-Aceituno et al., 2013)

Cumming D, 2010, J Bus Venturing (Cumming et al., 2010)

Dalton DR, 2011, J Manage (Dalton et al., 2011)

Khan HUZ, 2010, Int J Law Manage (H.-U.-Z. Khan et al., 2010)

Arora P, 2011, Corp Governance (Arora et al., 2011)

Munari F, 2010, Res Policy (Munari et al., 2010)

Estrin S, 2011, Asia Pac J Manage (Estrin et al., 2011)

Boubakri N, 2012, J Corp Finance (Boubakri et al., 2012)

Hoechle D, 2012, J Finance Econ (Hoechle et al., 2012)

Chau G, 2010, J Int Account Audit Tax (Chau et al., 2010)

Carcello JV, 2011, Auditing (Carcello et al., 2011)

Adams RB, 2012, J Finance Intermediation (Adams et al., 2012)

Levy D1, 2010, Bus Social (Levy et al., 2010)

Francis Jr, 2010, J Account Econ (Francis et al., 2010)

Hayes Rm, 2012, J Finance Econ (Hayes et al., 2012)

Talke K, 2010, Res Policy (Talke et al., 2011)

Choi Sb, 2011, Res Policy (Choi et al., 2011)

Murphy KJ, 2013, Handbook Econ Finance (Murphy, 2013)

Ertimur Y, 2010, J Corp Finance (Ertimur et al., 2010)

Jizi MI, 2013, J Bus Ethics (Jizi et al., 2014)

Miller D, 2013, Organ Science (Miller et al., 2013)

Black B, 2012, J Finance Econ (Black et al., 2012)

Aoki M, 2010, Corp In Evol Divers : Cogn, Governance, And Institutional Rules (Aoki, 2010)

Coles JL, 2012, J Finance Econ (Coles et al., 2012)

Lennox C, 2010, Contempt Account Res (Lennox et al., 2010)

Allegrini M, 2013, J Manage Governance (Allegrini et al., 2013)

Kim Y, 2014, J Bank Finance (Y. Kim et al., 2014)

\begin{tabular}{|c|c|}
\hline 211 & 23.44 \\
\hline 206 & 22.89 \\
\hline 205 & 22.78 \\
\hline 203 & 25.38 \\
\hline 195 & 32.50 \\
\hline 190 & 27.14 \\
\hline 184 & 23.00 \\
\hline 181 & 25.86 \\
\hline 176 & 22.00 \\
\hline 168 & 28.00 \\
\hline 164 & 20.50 \\
\hline 162 & 23.14 \\
\hline 162 & 23.14 \\
\hline 154 & 17.11 \\
\hline 153 & 19.12 \\
\hline 152 & 21.71 \\
\hline 144 & 16.00 \\
\hline 142 & 15.78 \\
\hline 135 & 19.29 \\
\hline 133 & 14.78 \\
\hline 127 & 15.88 \\
\hline 127 & 14.11 \\
\hline 125 & 20.83 \\
\hline 124 & 13.78 \\
\hline 120 & 15.00 \\
\hline 120 & 13.33 \\
\hline 119 & 14.88 \\
\hline 113 & 12.56 \\
\hline 112 & 14.00 \\
\hline 111 & 15.86 \\
\hline 107 & 15.29 \\
\hline 106 & 11.78 \\
\hline 105 & 13.12 \\
\hline 102 & 14.57 \\
\hline 102 & 11.33 \\
\hline 102 & 11.33 \\
\hline 101 & 14.43 \\
\hline 101 & 11.22 \\
\hline 99 & 12.38 \\
\hline 98 & 16.33 \\
\hline 97 & 10.78 \\
\hline 95 & 15.83 \\
\hline 94 & 15.67 \\
\hline 93 & 13.29 \\
\hline 93 & 10.33 \\
\hline 92 & 13.14 \\
\hline 92 & 10.22 \\
\hline 91 & 15.17 \\
\hline 90 & 18.00 \\
\hline
\end{tabular}

\section{Contribution of the countries}

One of the interesting areas of the interest is to learn more about the contribution of different countries in corporate governance. As we can observe from the results of Fig. 6, researchers from USA (305 papers), UK (71 papers), Australia (45 papers) and Canada (34 papers) have contributed the most on corporate governance. 


\section{Country Scientific Production}

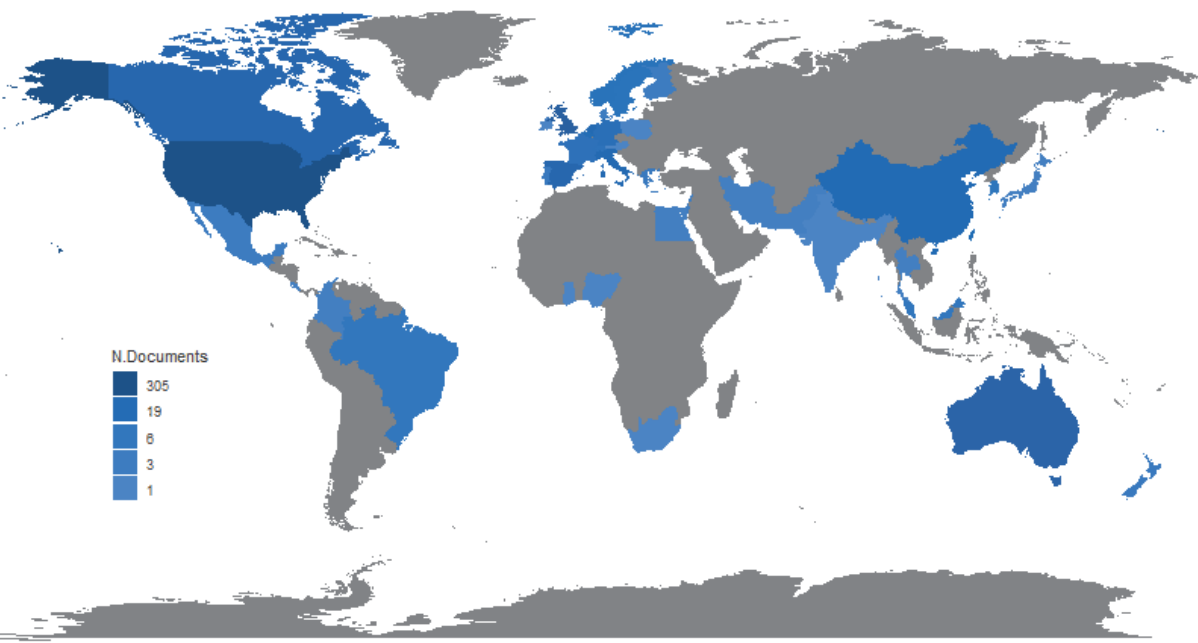

Fig. 6The frequency of the keywords used in different corporate governance studies

\section{Highest impact sources}

Table 5 demonstrates the highest source h-index associated with corporate governance. As we can observe from the results of Table 5, Corporate Governance: An International Review, Journal of Financial Economics, And Journal of Business Ethics are three well recognized keywords used in the literature. Fig. 7 shows the highest h-index Sources.

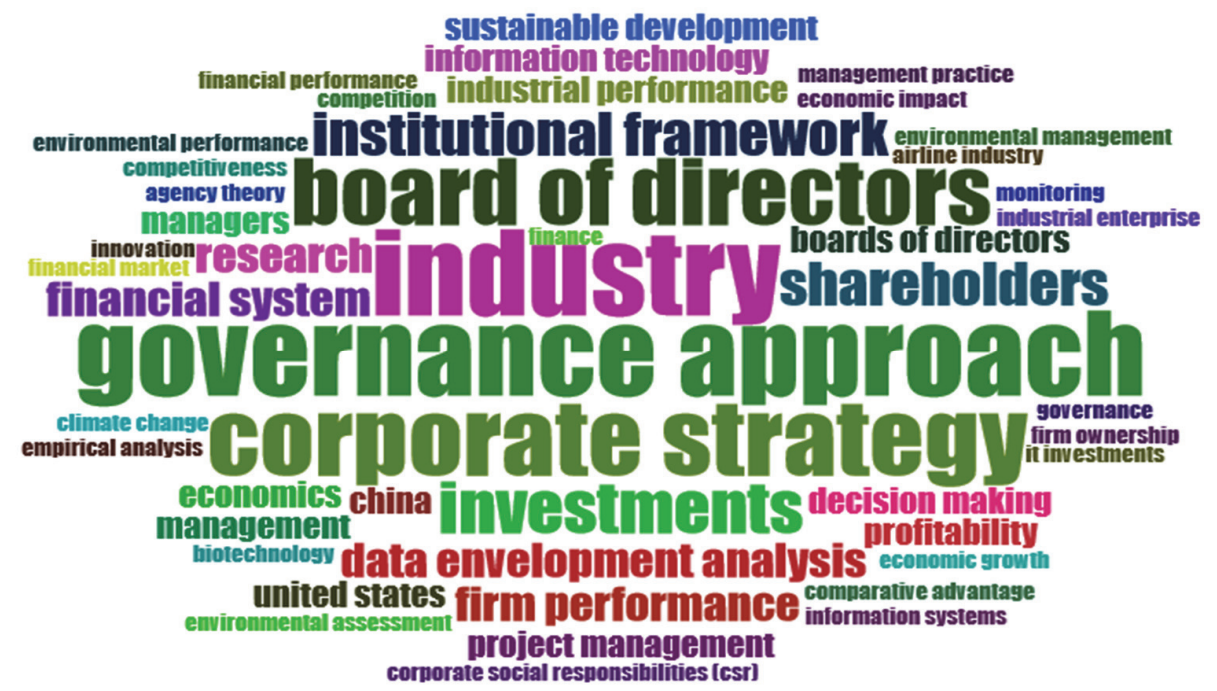

Fig. 7. The frequency of the keywords used in different corporate governance studies

\section{Conceptual structure map, Correspondence analysis}

Co-word analysis aims at representing the conceptual structure of a framework using co-occurrence of words. The words can be replaced by authors' keywords, keywords plus, and terms extracted from titles or abstracts. The conceptual structure function produces three kinds of mapping as listed: conceptual structure map, factorial map of the documents with the highest contributes and factorial map of the most cited documents. Conceptual structure map is shown in Fig. 2 where the gray cluster has the most keywords, which means the attention of the researchers to the subject matter of the study. 


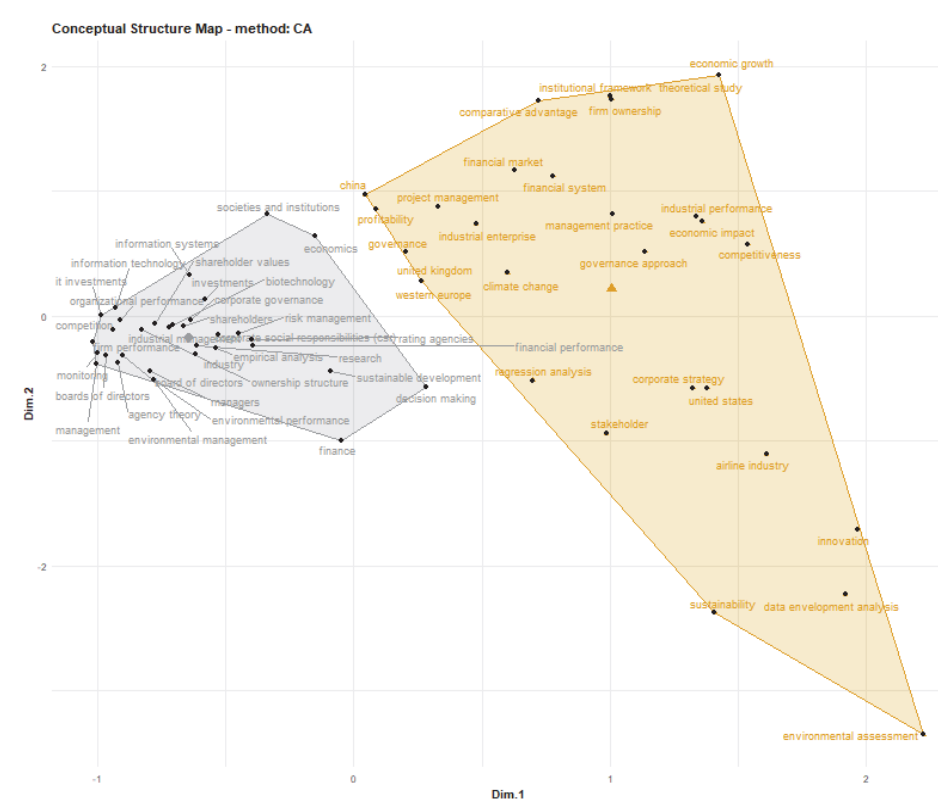

Fig. 8. Conceptual structure Map, method: CA

Mahadeo et al. (2012) and Xie et al. (2003) studied the key elements of the board diversity in the companies which act in the field of economy in Mauritius and analyzed their impacts on financial performance and focused on "Ownership Structure", when ownership is non-centralized, board autonomy and audit services are complementary. But this is not true when ownership is centralized. Their analysis also show that the controlling shareholder type affects the relationship between board composition and external audit costs (Desender et al., 2013).

\section{The most relevant sources}

Table 2 demonstrates some of the mostly relevant sources associated with corporate governance. As we can observe from the results of Table 2, "Corporate Governance: An International Review", "Journal of Financial Economics" and "Journal of Business Ethics" are three well recognized keywords used in the literature.

\section{Table 2}

The summary of the most relevant sources

\begin{tabular}{lc}
\hline Sources & Articles \\
\hline Corporate Governance: An International Review & 38 \\
Journal of Financial Economics & 36 \\
\hline Journal of Business Ethics & 32 \\
Journal of Corporate Finance & 20 \\
Strategic Management Journal & 12 \\
Journal of Accounting and Economics & 10 \\
Journal of Banking and Finance & 8 \\
Asia Pacific Journal of Management & 7 \\
Organization Science & 7 \\
Accounting Review & 6 \\
\hline Journal of International Business Studies & 5 \\
Journal of Management & 5 \\
Journal of Management and Governance & 5 \\
Research Policy & 5 \\
Corporate Social Responsibility and Environmental Management & 4 \\
Emerging Markets Review & 4 \\
\hline European Financial Management & 4 \\
Journal of Business Finance and Accounting & 4 \\
\hline Journal of Business Research & 4 \\
Managerial Auditing Journal & 4 \\
\hline
\end{tabular}


As it shows in Fig. 3 between 2010 up to 2016 all top related journals have approximately similar shares in issuing the number of article related to corporate governance in each year. But in 2017, this subject was only reflected in social responsibility and environment management journal. Maybe this is originated from the fact that CG issue has entered into social and environmental responsibility area, so these magazines have worked more about it. Also as seen in Fig. 3 in 2017, with the focus of the global community on corporate social responsibility and the acceptance of the culture of corporate social acceptance, the attention was unprecedentedly paid to the corporate governance aspect of social responsibility.

\section{Table 5}

The summary of the highest h-index sources

\begin{tabular}{lccccc}
\hline Sources & h-index & g-index & m-index & TC & NP \\
\hline Corporate Governance & 37 & 45 & 3.7 & 2942 & 45 \\
Corporate Governance: An International Review & 35 & 38 & 3.5 & 2431 & 38 \\
\hline Journal Of Financial Economics & 35 & 36 & 3.5 & 3364 & 36 \\
\hline Journal Of Business Ethics & 32 & 32 & 3.2 & 2923 & 32 \\
\hline Journal Of Management & 24 & 24 & 2.4 & 1540 & 24 \\
\hline Journal Of Corporate Finance & 20 & 20 & 2.0 & 1377 & 20 \\
\hline Auditing & 14 & 14 & 1.4 & 778 & 14 \\
\hline Strategic Management Journal & 12 & 12 & 1.2 & 801 & 12 \\
\hline Journal Of Accounting And Economics & 10 & 10 & 1.0 & 989 & 10 \\
\hline Journal Of Banking And Finance & 8 & 8 & 1.0 & 568 & 8 \\
\hline Asia Pacific Journal Of Management & 7 & 7 & 0.7 & 475 & 7 \\
\hline Organization Science & 7 & 7 & 0.8 & 491 & 7 \\
\hline Accounting Review & 7 & 7 & 0.7 & 491 & 7 \\
\hline Journal Of International Business Studies & 5 & 5 & 0.5 & 219 & 5 \\
\hline Journal Of Management And Governance & 5 & 5 & 0.5 & 255 & 5 \\
\hline Research Policy & 5 & 5 & 0.5 & 432 & 5 \\
\hline Corporate Social Responsibility And Environmental Management & 4 & 4 & 0.4 & 326 & 4 \\
\hline Emerging Markets Review & 4 & 4 & 0.4 & 359 & 4 \\
\hline European Financial Management & 4 & 4 & 0.4 & 224 & 4 \\
\hline Journal Of Business Finance And Accounting & 4 & 4 & 0.4 & 222 & 4 \\
\hline Journal Of Business Research & 4 & 4 & 0.4 & 182 & 4 \\
\hline Managerial Auditing Journal & 4 & 4 & 0.4 & 195 & 4 \\
\hline
\end{tabular}

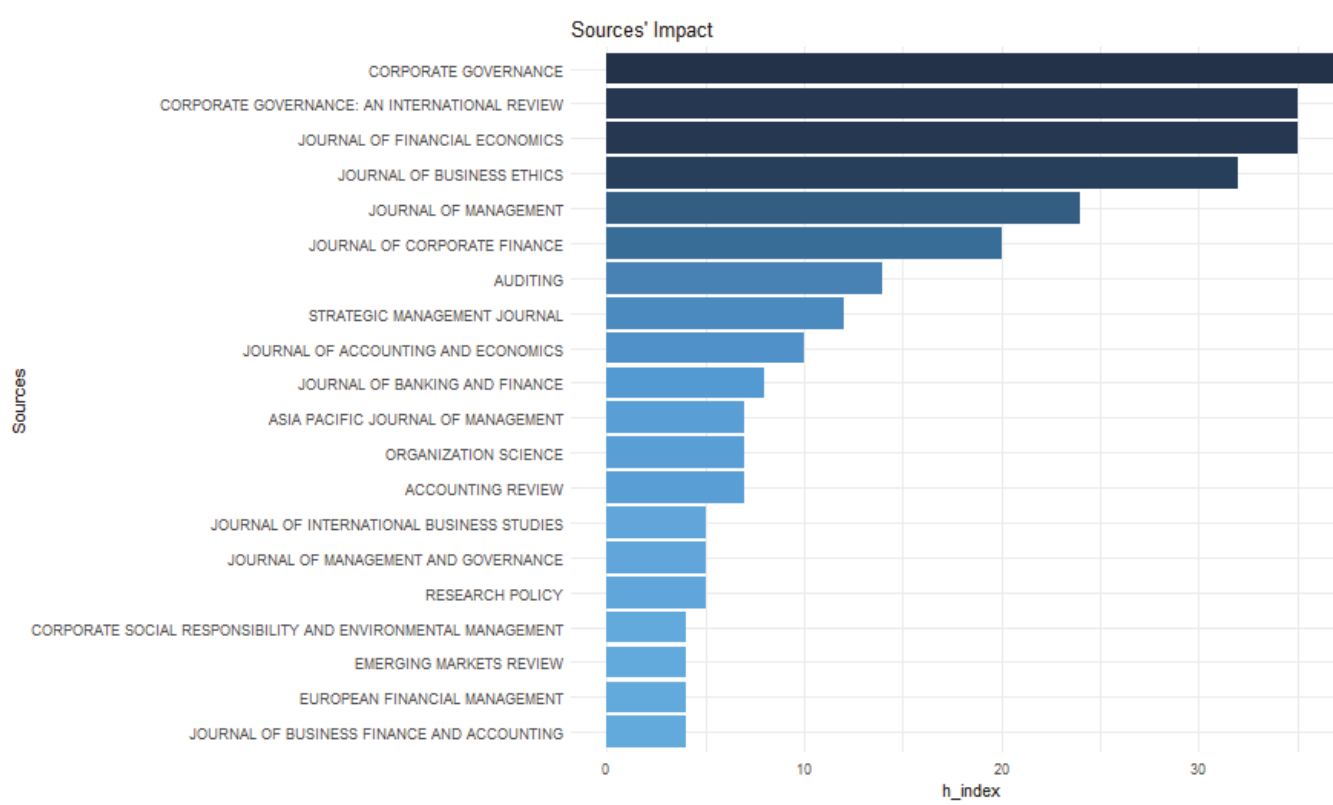

Fig. 7. The highest h-index sources associated with corporate governance 


\section{Authors}

Table 6 demonstrates highest Author's h-index associated with corporate governance. As we can observe from the results of Table 6, RENNEBOOG L, ARMSTRONG CS, and BOUBAKRI N are three highest h-index authors.

Fig. 8 shows Corresponding Author's Country in single country publications (SCP) \& multiple country publications (MCP) together.

\section{Table 6}

The summary of the highest Author's h-index

\begin{tabular}{|c|c|c|c|c|c|}
\hline Sources & h-index & g-index & m-index & $\mathrm{TC}$ & NP \\
\hline RENNEBOOG L & 6 & 6 & 0.6 & 255 & 6 \\
\hline ARMSTRONG CS & 4 & 4 & 0.4 & 444 & 4 \\
\hline BOUBAKRI N & 4 & 4 & 0.4 & 267 & 4 \\
\hline HUSE M & 4 & 4 & 0.4 & 530 & 4 \\
\hline NTIM CG & 4 & 4 & 0.5 & 242 & 4 \\
\hline AGUILERA RV & 3 & 3 & 0.4 & 200 & 3 \\
\hline BLACK BS & 3 & 3 & 0.3 & 151 & 3 \\
\hline FASSIN Y & 3 & 3 & 0.3 & 161 & 3 \\
\hline GARCÍA-MECA E & 3 & 3 & 0.3 & 139 & 3 \\
\hline HARJOTO MA & 3 & 3 & 0.3 & 545 & 3 \\
\hline JACKSON G & 3 & 3 & 0.3 & 558 & 3 \\
\hline $\mathrm{JOH}$ & 3 & 3 & 0.3 & 545 & 3 \\
\hline LARCKER DF & 3 & 3 & 0.3 & 226 & 3 \\
\hline LI S & 3 & 3 & 0.3 & 232 & 3 \\
\hline LI Y & 3 & 3 & 0.3 & 252 & 3 \\
\hline MULLER-KAHLE MI & 3 & 3 & 0.3 & 145 & 3 \\
\hline SAFFAR W & 3 & 3 & 0.37 & 229 & 3 \\
\hline WESTPHAL JD & 3 & 3 & 0.3 & 151 & 3 \\
\hline
\end{tabular}

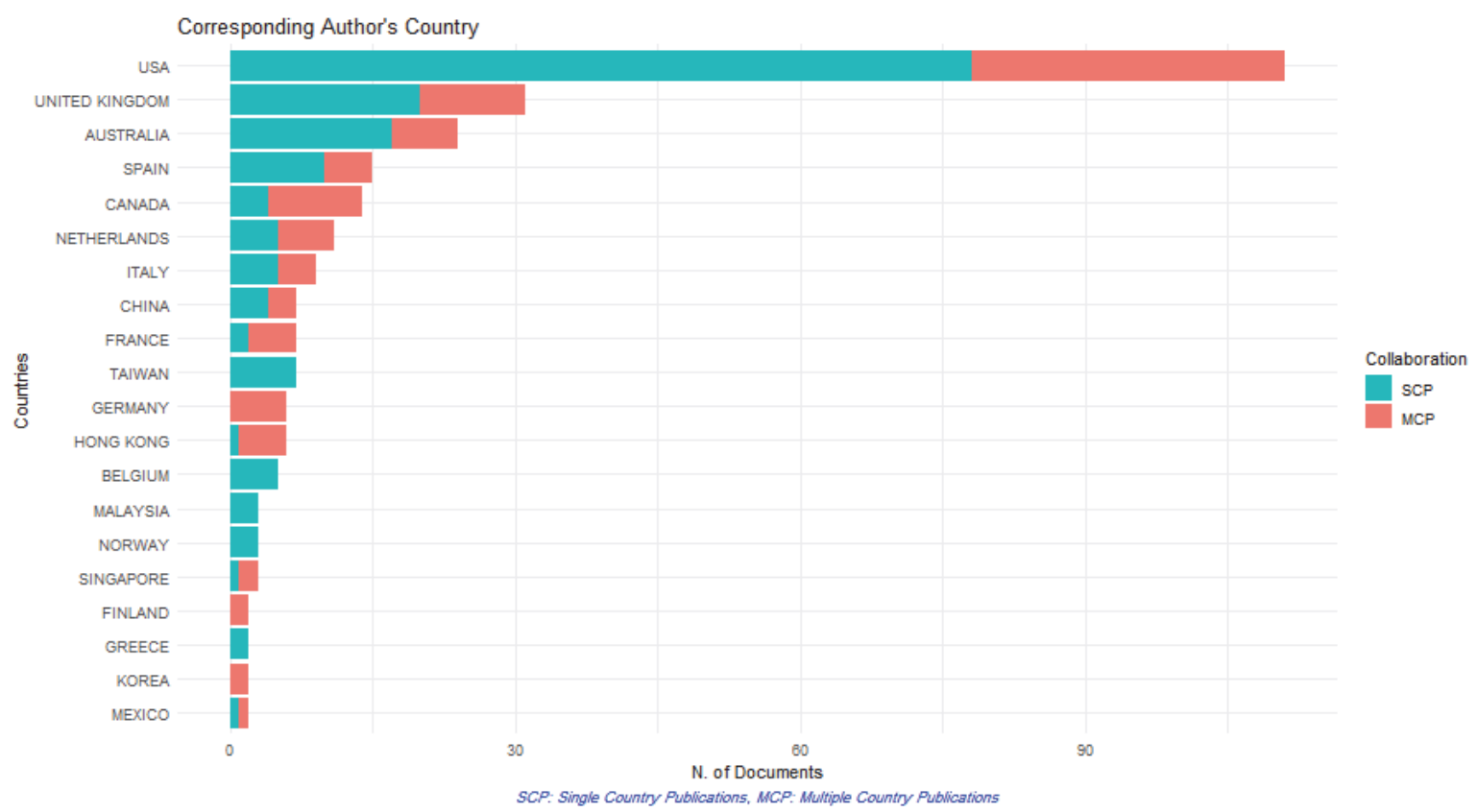

Fig. 8. Corresponding Author's Country 


\section{Conclusion}

One of the requirements of stock market is that investors should have access to financial information about a company such as price levels, market depth and audited financial reports. Information transparency improves the performance of companies in terms of their stock's performance. This matter has motivated companies' tendency to get more involved to provide disclosure. Corporate Governance and firms' clarity of information environment helps over time alleviate agency conflicts. Reducing information asymmetries between contracting parties will evolve to certain business environments (Armstrong et al., 2010). Recent research has recorded a significant difference between countries in the concentration of ownership, breadth and depth of capital markets, dividend policies and the access to external finance. The common element of these items is Corporate Governance. The effects of owner identity and external corporate governance systems on R\&D investments represents that countries like the United Kingdom invest less in R \& D than European countries. This leads to the pressure to decrease the R \& D in Corporate Governance (Munari et al., 2010).

In order to analyze the process of scientific works carried out in the field of CG from 2010 to 2018, we have performed a comparison between the documents released between from 1993 to 2009 and from 2010 to 2018 . First, it is interesting to note the following several interesting items:

- As was mentioned before in this study, 2000 documents were selected from Scopus. The oldest articles in this period of time were related to 1993

- The highest cited article is 2349 which was published in 1996.

- During the 2010-2017, the highest cited article was 420.

- During the 2000-2009, the highest cited article was 2152.

The following items are based on a random selection of articles related to the topic of CG, from 1993 to 2009:

- Small boards are more effective for companies and make more pleasant values on financial ratios and stronger CEO performance encouragement (Yermack, 1996).

- The study of the effect of chief executive officer compensation on Firm Performance pointed out that the standard economic determinants of pay, after measures of board and ownership structure, affect the change of CEO compensation.

- Firms which have weaker governance structures, have greater agency problems. Firms with greater agency problems perform worse, although they pay greater compensation to CEOs. (Core et al., 1999)

- The role of the board and the audit committee in connection with the earnings management and Corporate Governance suggests that the composition of a board and audit committee members, is associated with the probability of being involved in earnings management. The measures and financial sophistication of the board and the audit committee may be an important factor to encourage them to participate in earnings management (Xie et al., 2003).

- The decisions of the companies regarding the structure of capital are affected by the environment they operate in it. The 1997 financial crisis had a significant impact on it (Deesomsak et al., 2004).

- In the context of Fairness and Executive Compensation, the effect of fairness on top decisionmakers has been discussed.

- Managers use their power to increase their salaries and their subordinates. Employees perceive their situation as fair or not in comparison with the managers and thus react to their own compensation (Wade et al., 2006).

- By comparison of CG with Costs, Contingencies, and Complementarities, the effectiveness of CG and the implications on policy was analyzed. Most studies do not consider the interdependence between the organization and the environment while this leads to changes in the actions related to CG. Costs, Contingencies, and Complementarities are helpful in analyzing CG (Aguilera et al., 2013). 
- The ownership structure affects stakeholder engagement and corporate social responsibility reporting.

- Shareholder power and dispersed ownership structure influence on information disclosure of firms pertinent to corporate social responsibility (CSR) (Prado-Lorenz et al., 2006)/

Fig. 9 shows the number of articles published annually from 1993 to 2018.

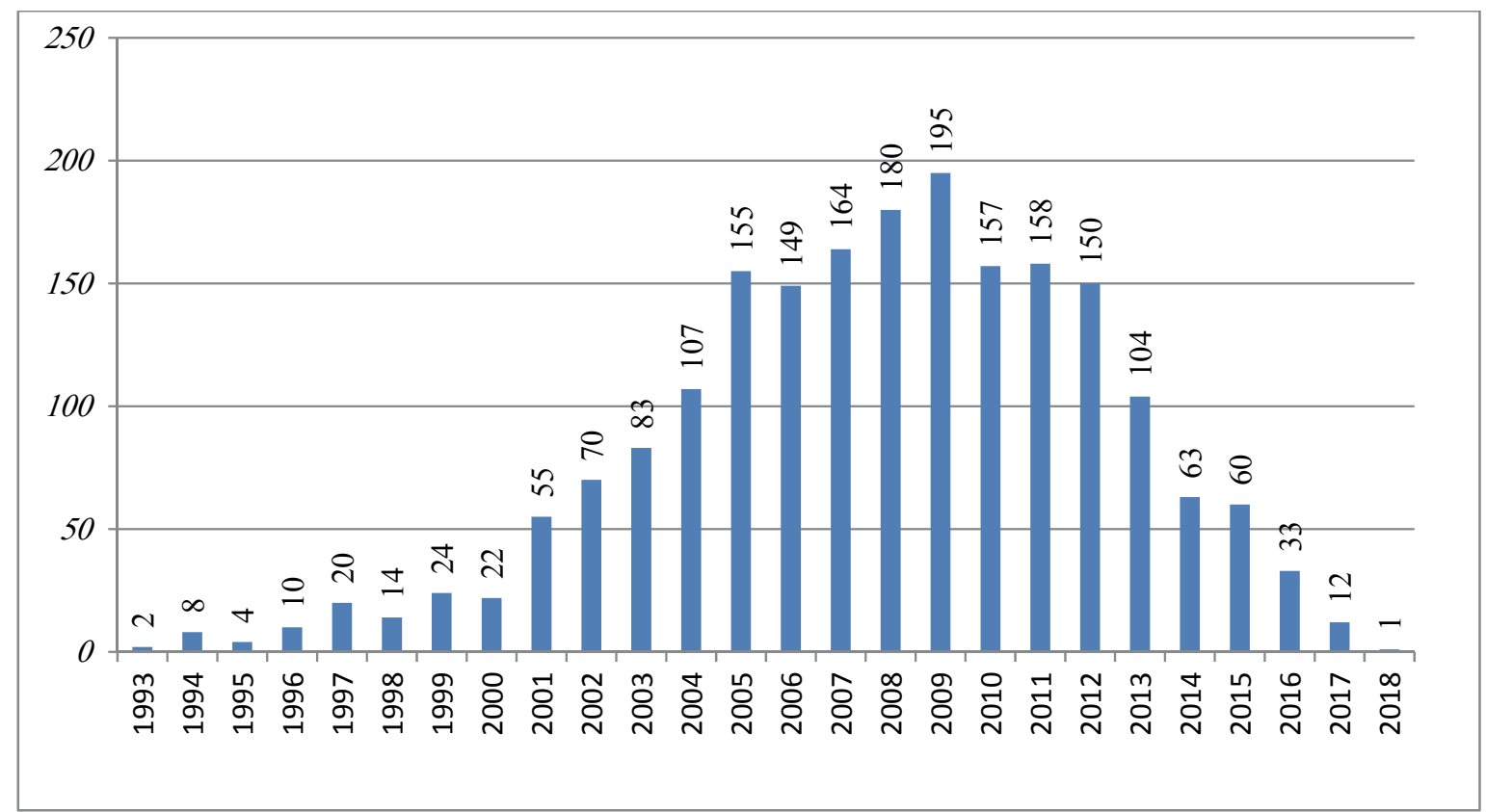

Fig. 9.The Scopus publication on Corporate Governance from 1993 to 2018

By comparing the charts and graphs of 2010 to 2017 with 1993 to 2009, we have noted that the trend of scientific production in the case of corporate governance, from 1993 to 2009, has had a growing policy. Investigation into the factors involved in the emergence of this trend is suggested as future study. From 2010 to 2017 on the contrary, we see a descending trend of the process of scientific production of countries, which requires an independent investigation as future study.

Considering the competitive advantage of business in today's life and the more instability of environmental conditions, choosing the appropriate strategy related to the topic of CG plays a more important role.

\section{Acknowledgement}

The authors would like to thank the anonymous referees for constructive comments on earlier version of this paper.

\section{References}

Adams, R. B., \& Mehran, H. (2012). Bank board structure and performance: Evidence for large bank holding companies. Journal of Financial Intermediation, 21(2), 243-267.

Aebi, V., Sabato, G., \& Schmid, M. (2012). Risk management, corporate governance, and bank performance in the financial crisis. Journal of Banking \& Finance, 36(12), 3213-3226.

Aggarwal, R., Erel, I., Ferreira, M., \& Matos, P. (2011). Does governance travel around the world? Evidence from institutional investors. Journal of Financial Economics, 100(1), 154-181. 
Aguilera, R. V., Filatotchev, I., Gospel, H., \& Jackson, G. (2008). An organizational approach to comparative corporate governance: Costs, contingencies, and complementarities. Organization Science, 19(3), 475-492.

Allegrini, M., \& Greco, G. (2013). Corporate boards, audit committees and voluntary disclosure: Evidence from Italian listed companies. Journal of Management \& Governance, 17(1), 187-216.

Aoki, M. (2010). Corporations in evolving diversity: Cognition, governance, and institutions: Oxford University Press.

Armstrong, C. S., Guay, W. R., \& Weber, J. P. (2010). The role of information and financial reporting in corporate governance and debt contracting. Journal of Accounting and Economics, 50(2-3), 179234.

Arora, P., \& Dharwadkar, R. (2011). Corporate governance and corporate social responsibility (CSR): The moderating roles of attainment discrepancy and organization slack. Corporate Governance: An International Review, 19(2), 136-152.

Barnea, A., \& Rubin, A. (2010). Corporate social responsibility as a conflict between shareholders. Journal of business ethics, 97(1), 71-86.

Bebchuk, L. A., Cremers, K. M., \& Peyer, U. C. (2011). The CEO pay slice. Journal of financial economics, 102(1), 199-221.

Ben-Amar, W., Chang, M., \& McIlkenny, P. (2017). Board gender diversity and corporate response to sustainability initiatives: Evidence from the carbon disclosure project. Journal of business ethics, 142(2), 369-383.

Black, B., \& Kim, W. (2012). The effect of board structure on firm value: A multiple identification strategies approach using Korean data. Journal of financial economics, 104(1), 203-226.

Boubakri, N., Guedhami, O., Mishra, D., \& Saffar, W. (2012). Political connections and the cost of equity capital. Journal of corporate finance, 18(3), 541-559.

Brammer, S., Jackson, G., \& Matten, D. (2012). Corporate social responsibility and institutional theory: New perspectives on private governance. Socio-economic review, 10(1), 3-28.

Brown, P., Beekes, W., \& Verhoeven, P. (2011). Corporate governance, accounting and finance: A review. Accounting \& finance, 51(1), 96-172.

Carcello, J. V., Hermanson, D. R., \& Ye, Z. (2011). Corporate governance research in accounting and auditing: Insights, practice implications, and future research directions. Auditing: A Journal of Practice \& Theory, 30(3), 1-31.

Carter, D. A., D'Souza, F., Simkins, B. J., \& Simpson, W. G. (2010). The gender and ethnic diversity of US boards and board committees and firm financial performance. Corporate Governance: An International Review, 18(5), 396-414.

Chau, G., \& Gray, S. J. (2010). Family ownership, board independence and voluntary disclosure: Evidence from Hong Kong. Journal of International Accounting, Auditing and Taxation, 19(2), 93109.

Choi, S. B., Lee, S. H., \& Williams, C. (2011). Ownership and firm innovation in a transition economy: Evidence from China. Research Policy, 40(3), 441-452.

Claessens, S., \& Yurtoglu, B. B. (2013). Corporate governance in emerging markets: A survey. Emerging markets review, 15, 1-33.

Cohen, J., Krishnamoorthy, G., \& Wright, A. (2010). Corporate governance in the post-Sarbanes-Oxley era: Auditors' experiences. Contemporary Accounting Research, 27(3), 751-786.

Coles, J. L., Lemmon, M. L., \& Meschke, J. F. (2012). Structural models and endogeneity in corporate finance: The link between managerial ownership and corporate performance. Journal of financial economics, 103(1), 149-168.

Core, J. E., Holthausen, R. W., \& Larcker, D. F. (1999). Corporate governance, chief executive officer compensation, and firm performance1. Journal of financial economics, 51(3), 371-406.

Cumming, D., Schmidt, D., \& Walz, U. (2010). Legality and venture capital governance around the world. Journal of Business Venturing, 25(1), 54-72. 
Dalton, D. R., \& Dalton, C. M. (2011). Integration of micro and macro studies in governance research: CEO duality, board composition, and financial performance. In: SAGE Publications Sage CA: Los Angeles, CA.

Deesomsak, R., Paudyal, K., \& Pescetto, G. (2004). The determinants of capital structure: evidence from the Asia Pacific region. Journal of multinational financial management, 14(4-5), 387-405.

Desender, K. A., Aguilera, R. V., Crespi, R., \& GarcÍa-cestona, M. (2013). When does ownership matter? Board characteristics and behavior. Strategic Management Journal, 34(7), 823-842.

Duchin, R., Matsusaka, J. G., \& Ozbas, O. (2010). When are outside directors effective? Journal of financial economics, 96(2), 195-214.

Erkens, D. H., Hung, M., \& Matos, P. (2012). Corporate governance in the 2007-2008 financial crisis: Evidence from financial institutions worldwide. Journal of corporate finance, 18(2), 389-411.

Ertimur, Y., Ferri, F., \& Stubben, S. R. (2010). Board of directors' responsiveness to shareholders: Evidence from shareholder proposals. Journal of corporate finance, 16(1), 53-72.

Estrin, S., \& Prevezer, M. (2011). The role of informal institutions in corporate governance: Brazil, Russia, India, and China compared. Asia Pacific journal of management, 28(1), 41-67.

Francis, J. R., \& Martin, X. (2010). Acquisition profitability and timely loss recognition. Journal of Accounting and Economics, 49(1-2), 161-178.

Frias-Aceituno, J. V., Rodriguez-Ariza, L., \& Garcia-Sanchez, I. M. (2013). The role of the board in the dissemination of integrated corporate social reporting. Corporate Social Responsibility and Environmental Management, 20(4), 219-233.

Frydman, C., \& Jenter, D. (2010). CEO compensation. Annu. Rev. Financ. Econ., 2(1), 75-102.

Gedajlovic, E., Carney, M., Chrisman, J. J., \& Kellermanns, F. W. (2012). The adolescence of family firm research: Taking stock and planning for the future. Journal of Management, 38(4), 1010-1037.

Gibbs, P. A. (1993). Determinants of corporate restructuring: The relative importance of corporate governance, takeover threat, and free cash flow. Strategic Management Journal, 14(S1), 51-68.

Giroud, X., \& Mueller, H. M. (2010). Does corporate governance matter in competitive industries? Journal of financial economics, 95(3), 312-331.

Harjoto, M. A., \& Jo, H. (2011). Corporate governance and CSR nexus. Journal of business ethics, $100(1), 45-67$.

Hayes, R. M., Lemmon, M., \& Qiu, M. (2012). Stock options and managerial incentives for risk taking: Evidence from FAS 123R. Journal of financial economics, 105(1), 174-190.

Hoechle, D., Schmid, M., Walter, I., \& Yermack, D. (2012). How much of the diversification discount can be explained by poor corporate governance? Journal of financial economics, 103(1), 41-60.

Jackson, G., \& Apostolakou, A. (2010). Corporate social responsibility in Western Europe: an institutional mirror or substitute? Journal of business ethics, 94(3), 371-394.

Jian, M., \& Wong, T. J. (2010). Propping through related party transactions. Review of Accounting Studies, 15(1), 70-105.

Jizi, M. I., Salama, A., Dixon, R., \& Stratling, R. (2014). Corporate governance and corporate social responsibility disclosure: Evidence from the US banking sector. Journal of business ethics, 125(4), 601-615.

Jo, H., \& Harjoto, M. A. (2011). Corporate governance and firm value: The impact of corporate social responsibility. Journal of business ethics, 103(3), 351-383.

Jo, H., \& Harjoto, M. A. (2012). The causal effect of corporate governance on corporate social responsibility. Journal of business ethics, 106(1), 53-72.

Khan, A., Muttakin, M. B., \& Siddiqui, J. (2013). Corporate governance and corporate social responsibility disclosures: Evidence from an emerging economy. Journal of business ethics, 114(2), 207-223.

Khan, H.-U.-Z. (2010). The effect of corporate governance elements on corporate social responsibility (CSR) reporting: Empirical evidence from private commercial banks of Bangladesh. International Journal of Law and Management, 52(2), 82-109.

Kim, J.-B., Li, Y., \& Zhang, L. (2011). CFOs versus CEOs: Equity incentives and crashes. Journal of financial economics, 101(3), 713-730. 
Kim, Y., Li, H., \& Li, S. (2014). Corporate social responsibility and stock price crash risk. Journal of Banking \& Finance, 43, 1-13.

Le Breton-Miller, I., Miller, D., \& Lester, R. H. (2011). Stewardship or agency? A social embeddedness reconciliation of conduct and performance in public family businesses. Organization science, 22(3), 704-721.

Lennox, C., \& Pittman, J. A. (2010). Big Five audits and accounting fraud. Contemporary Accounting Research, 27(1), 209-247.

Levy, D. L., Szejnwald Brown, H., \& De Jong, M. (2010). The contested politics of corporate governance: The case of the global reporting initiative. Business \& Society, 49(1), 88-115.

Li, W., \& Zhang, R. (2010). Corporate social responsibility, ownership structure, and political interference: Evidence from China. Journal of business ethics, 96(4), 631-645.

Mahadeo, J. D., Soobaroyen, T., \& Hanuman, V. O. (2012). Board composition and financial performance: Uncovering the effects of diversity in an emerging economy. Journal of business ethics, 105(3), 375-388.

Mahoney, J. M., \& Mahoney, J. T. (1993). An empirical investigation of the effect of corporate charter antitakeover amendments on stockholder wealth. Strategic Management Journal, 14(1), 17-31.

Masulis, R. W., Wang, C., \& Xie, F. (2012). Globalizing the boardroom-The effects of foreign directors on corporate governance and firm performance. Journal of Accounting and Economics, 53(3), 527-554.

Miller, D., Breton-Miller, I. L., \& Lester, R. H. (2013). Family firm governance, strategic conformity, and performance: Institutional vs. strategic perspectives. Organization science, 24(1), 189-209.

Munari, F., Oriani, R., \& Sobrero, M. (2010). The effects of owner identity and external governance systems on R\&D investments: A study of Western European firms. Research Policy, 39(8), 1093 1104.

Murphy, K. J. (2013). Executive compensation: Where we are, and how we got there. In Handbook of the Economics of Finance (Vol. 2, pp. 211-356): Elsevier.

Nielsen, S., \& Huse, M. (2010). The contribution of women on boards of directors: Going beyond the surface. Corporate Governance: An International Review, 18(2), 136-148.

Prado-Lorenzo, J. M., Gallego-Alvarez, I., \& Garcia-Sanchez, I. M. (2009). Stakeholder engagement and corporate social responsibility reporting: the ownership structure effect. Corporate Social Responsibility and Environmental Management, 16(2), 94-107.

Schrand, C. M., \& Zechman, S. L. (2012). Executive overconfidence and the slippery slope to financial misreporting. Journal of Accounting and Economics, 53(1-2), 311-329.

Shleifer, A., Vishny, R. W., Porta, R., \& Lopez-de-Silanes, F. (2000). Investor protection and corporate governance. Journal of financial economics, 58(1-2), 3-27.

Song, C. J., Thomas, W. B., \& Yi, H. (2010). Value relevance of FAS No. 157 fair value hierarchy information and the impact of corporate governance mechanisms. The Accounting Review, 85(4), 1375-1410.

Talke, K., Salomo, S., \& Rost, K. (2010). How top management team diversity affects innovativeness and performance via the strategic choice to focus on innovation fields. Research Policy, 39(7), 907918.

Torchia, M., Calabrò, A., \& Huse, M. (2011). Women directors on corporate boards: From tokenism to critical mass. Journal of business ethics, 102(2), 299-317.

Tuggle, C. S., Sirmon, D. G., Reutzel, C. R., \& Bierman, L. (2010). Commanding board of director attention: investigating how organizational performance and CEO duality affect board members' attention to monitoring. Strategic Management Journal, 31(9), 946-968.

Wade, J. B., O'Reilly III, C. A., \& Pollock, T. G. (2006). Overpaid CEOs and underpaid managers: Fairness and executive compensation. Organization science, 17(5), 527-544.

Walls, J. L., Berrone, P., \& Phan, P. H. (2012). Corporate governance and environmental performance: Is there really a link? Strategic Management Journal, 33(8), 885-913.

Wintoki, M. B., Linck, J. S., \& Netter, J. M. (2012). Endogeneity and the dynamics of internal corporate governance. Journal of Financial Economics, 105(3), 581-606. 
Xie, B., Davidson III, W. N., \& DaDalt, P. J. (2003). Earnings management and corporate governance: the role of the board and the audit committee. Journal of corporate finance, 9(3), 295-316.

Yermack, D. (1996). Higher market valuation of companies with a small board of directors. Journal of financial economics, 40(2), 185-211.

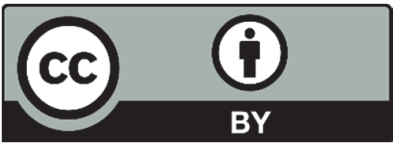

(C) 2019 by the authors; licensee Growing Science, Canada. This is an open access article distributed under the terms and conditions of the Creative Commons Attribution (CC-BY) license (http://creativecommons.org/licenses/by/4.0/). 